\title{
OPINION
}

\section{Harm, hype and evidence: ELSI research and policy guidance}

\author{
Timothy Caulfield ${ }^{1 *}$, Subhashini Chandrasekharan², Yann Joly ${ }^{3}$ and Robert Cook-Deegan²
}

\begin{abstract}
There has been much investment in research on the ethical, legal and social issues (ELSI) associated with genetic and genomic research. This research should inform the development of the relevant policy. So far, much of the relevant policy - such as in the areas of patents, genetic testing and genetic discrimination seems to be informed more by speculation of harm and anecdote than by available evidence. Although a quest for evidence cannot always be allowed to delay policy choice, it seems axiomatic to us that policy options are improved by the incorporation of evidence.
\end{abstract}

\section{Genomics and ELSI research}

With the announcement of the Human Genome Project came speculation about a host of profound social challenges. Indeed, few areas of scientific inquiry have been subject to as much ethical scrutiny as genetics, and no scientific program has so systematically fostered the study of ethical, legal and social implications (ELSI) in parallel. This ELSI literature has led to a great deal of public debate, policymaking and the enactment of national legislation (for example, $[1,2]$ ) and international declarations [3]. But what does the available evidence tell us about the relevant social harms? Is the field of genomics really causing social issues worthy of a formal policy response? In fact, the ethical, legal and social harms associated with genetics and genomics - be they in relation to patients, research participants, the research community or society more broadly - have turned out to be less certain and often less severe than originally anticipated, a point often neglected in public debates about genetic policy.

Emerging empirical evidence, which has been gathered by ELSI researchers throughout the world, has shed new

*Correspondence: tcaulfld@law.ualberta.ca

'Health Law and Science Policy Group, University of Alberta, Edmonton, Alberta

Canada, T6G 2H5

Full list of author information is available at the end of the article light on many of the social challenges associated with genomics, including three of the most common areas of concern: the impact of gene patents, genetic discrimination, and testing-induced harm. For these areas which, of course, merely serve as examples of the many ELSI topics associated with genomic research - there are data that tell us that some harms exist. And these issues should not be ignored. But, as with the science of genomics, ELSI research reveals a more complex situation that is less amenable to definitive conclusions than often portrayed. As highlighted below, the available evidence - that is, the evidence that is the result of an academic research study and not mere anecdote - tells us that the speculated harms have not, in general, materialized to the degree often suggested in the realm of popular discourse (for examples of such discourse see Table 1).

Despite this reality, many policy choices have been made, such as the enactment of legislation to curb discrimination and, in some jurisdictions, bans on public access to genetic tests. It seems that these policy moves have been based not on empirical evidence, but more on anecdote and speculation of possible harm. Although a quest for evidence cannot always be allowed to delay policy choice, policy options are surely the better for incorporating evidence when it exists. And when no data exist, ELSI research programs can sometimes fund projects to fill data gaps. This has important implications for public debates, policy development and the future of ELSI research. Future genomic policy should, as much as politically practical, be informed by and responsive to the relevant ELSI evidence.

\section{ELSI examples}

\section{Genetic patents}

Patents on human gene sequences have been controversial from the start [4]. Although patent litigation, until recently, has centered mostly on gene patents for therapeutic proteins, such as insulin, growth hormone, and erythropoietin [5], most of the controversy has instead centered on concerns that gene patents might encumber clinical access to genetic testing and impede clinical and basic research. Indeed, as noted in Table 1, 
Table 1. Examples of public discourse on ELSI

\begin{tabular}{|c|c|c|}
\hline & Quote & Source \\
\hline \multirow[t]{4}{*}{ Patents } & $\begin{array}{l}\text { "The AMA [American Medical Association] is opposed to gene patenting because } \\
\text { it has the potential to inhibit access to genetic testing for patients and hinder } \\
\text { research on genetic disease." }\end{array}$ & $\begin{array}{l}\text { American Medical Association website } \\
\text { [45] }\end{array}$ \\
\hline & $\begin{array}{l}\text { "[W]e believe [gene patenting] may potentially...[l]ead to significant limitations } \\
\text { in genetic research...[s]tifle the development of innovative tests ... and [c]reate } \\
\text { exorbitant licensure costs that will be passed on to the consumer." }\end{array}$ & $\begin{array}{l}\text { National Society of Genetic Counselors, } \\
2010[46]\end{array}$ \\
\hline & $\begin{array}{l}\text { "It's wrong to think that something as naturally occurring as DNA can be } \\
\text { patented by a single company that limits scientific research and the free } \\
\text { exchange of ideas..." }\end{array}$ & $\begin{array}{l}\text { Chris Hansen, American Civil Liberties } \\
\text { Union staff lawyer, in an interview with the } \\
\text { Huffington Post, } 2012 \text { [47] }\end{array}$ \\
\hline & $\begin{array}{l}\text { "You, or someone you love, may die because of a gene patent that should never } \\
\text { have been granted in the first place." }\end{array}$ & $\begin{array}{l}\text { Michael Crichton, The New York Times, } \\
2007 \text { [48] }\end{array}$ \\
\hline \multirow[t]{3}{*}{ Testing anxiety } & "Gene tests 'create undue stress"' & BBC News, 2008 [49] \\
\hline & $\begin{array}{l}\text { "The emotional impact of positive test results can be significant and can cause } \\
\text { persistent worry, confusion, anger, depression, and even despair." }\end{array}$ & $\begin{array}{l}\text { US Secretary's Advisory Committee on } \\
\text { Genetic Testing, } 2000 \text { [19] }\end{array}$ \\
\hline & $\begin{array}{l}\text { "Genetic testing can help patients make decisions if the information means } \\
\text { something specific, but often, it doesn't. In fact, these journeys often bring } \\
\text { intense anxiety due to the uncertainty - what one researcher calls'toxic } \\
\text { knowledge.". }\end{array}$ & $\begin{array}{l}\text { Ricki Lewis, Scientific American blog, } \\
2012 \text { [50] }\end{array}$ \\
\hline \multirow[t]{3}{*}{ Genetic discrimination } & "Genetic discrimination affects us all! Who has perfect genes?" & $\begin{array}{l}\text { Canadian Coalition for Genetic Fairness } \\
\text { website [51] }\end{array}$ \\
\hline & "Gene testing exposes us all to discrimination" & Sydney Morning Herald, 2010 [52] \\
\hline & $\begin{array}{l}\text { "Fear of misuse is already preventing people from undergoing genetic testing } \\
\text { and participating in clinical trials that are needed to treat disease." }\end{array}$ & Globe and Mail, 2012 [53] \\
\hline
\end{tabular}

some commentators, such as author Michael Crichton, have gone so far as to suggest that gene patents may lead to unjustified deaths.

But what does the evidence actually say? Although early and relatively small studies suggested that patents and exclusive licensing reduced availability of genetic testing [6,7], recent empirical analysis has found little evidence that patents substantially or pervasively hinder provision of clinical genetic testing [8-11]. Evidence is also ambiguous about patent effects on test prices [8], basic research and the degree to which patents have created incentives for genetic test development for the majority of Mendelian genetic disorders. Data on whether, and to what extent, patents may foster or hinder development of promising new clinical technologies, such as highly parallel multigene tests and clinical wholegenome/exome sequencing, are only just emerging [12] and are in no way conclusive. A shadow of uncertainty due to patent infringement liability hovers over wholegenome/exome sequencing tests, but initial empirical work suggests that there may be greater freedom to operate than perceived $[13,14]$.

Despite the equivocal nature of the evidence, controversy persists, as highlighted by ongoing litigation over the patents filed by Myriad Genetics, Inc. (Salt Lake City, Utah, USA) on the BRCA1 and BRCA2 breast cancer genes in the US and a parallel case in Australia. Indeed, the US litigation, sponsored by the American Civil Liberties Union and Public Patent Foundation [15], has become by far the most conspicuous gene patent case in history. $B R C A$ patents have already been the subject of intense policy debate in Europe, Australia and Canada. The case has generated intense media attention, which, like previous media discourse about $B R C A$ gene patents [16], has been decidedly negative - probably partly as a result of Myriad's business practices, which have alienated physicians, researchers and patients. This highprofile case created a narrative that seems to support the social concerns so often associated with patents. But, in reality, this case stands as an example of the power of an anecdote or outlier case rather than definitive proof of systemic problems [17].

In total, the available evidence tells us that the alleged harms (and, for that matter, the suggested benefits) of human gene patenting have been overstated and oversimplified. Studies, in fact, reveal a more nuanced picture.

\section{Testing-induced harm}

One of the core concerns associated with the emergence of genetic testing technologies - particularly in the context of direct-to-consumer (DTC) testing - is that the information on genetic risk will cause harm. With the 
increasing public availability of a range of testing services, including tests for both relatively superficial traits such as athletic ability and those that disclose the risk of potentially serious diseases, many speculated that genetic test results could be misinterpreted, encourage unhealthy and fatalistic behavior, and cause anxiety and even depression $[18,19]$. The large numbers of unreliable genetic tests offered to the public on the Internet was also perceived as a potential threat to the efficient running of public healthcare systems. These concerns have been at the heart of calls for regulation and oversight $[19,20]$.

So far, however, there is little evidence to support the idea that, in general, people have an adverse or unhealthy reaction to genetic risk information [21]. Although the data are still emerging and most commentators seem to agree that accurate advertising and testing is essential [22], the relevant studies have found little evidence of fatalism [22] or persistent increased anxiety [23]. Indeed, genetic risk information seems to have little long-term impact of any kind on perceptions or behavior [24,25]. Of course, this does not mean that there are no issues; certain individuals or groups may be more sensitive and, thus, more likely to react poorly to genetic 'bad news' or feel survivor guilt for 'good news' when others in their family have deleterious mutations. But the data do raise questions about the magnitude of the problem and the ways in which policy-makers might respond, which, so far, have included everything from outright bans on DTC testing to the suggestion (and in Germany, a national law) that genetic testing should only be provided by a licenced health professional [26].

\section{Genetic discrimination}

Reports predicting the emergence of a new genetic underclass who would be excluded from many aspects of social life (for example, unable to get life or health insurance, or being discriminated against in getting a job) have emerged steadily in scientific and popular media over the past 20 years $[27,28]$. As a result of these reports, genetic discrimination emerged as a dominant social concern leading to a range of policy responses. In Europe, concern over genetic discrimination has resulted in the adoption of a plethora of laws, guidelines and policies, both at the regional (Council of Europe, European Union) and national level [29]. In the US and the UK, and more recently Australia, legislators have felt compelled to adopt protective legal measures specifically addressing discrimination [30,31]. For example, in the US, the Genetic Information Nondiscrimination Act addressed health insurance and job discrimination, and provisions of the Health Insurance Portability and Accountability Act [32] and the Patient Protection and Affordable Care Act [33] also incorporated genetic nondiscrimination provisions.
Despite all this policy action, there is, in fact, little evidence suggesting that genetic discrimination is a significant or common social phenomenon [34]. Some studies have suggested cases of genetic discrimination in the UK, North America and Australia, but important methodological limitations, contradictory results and the limited number of genetic conditions surveyed make it difficult to justify broad policy actions solely on the basis of this inconsistent empirical research [35]. At a minimum, it seems safe to conclude that the evidence of harm is not commensurate with the amount of policy attention the issue has received.

Of course, as with all of these areas, evidence of harm has rarely been the main driver of policy regarding genetic discrimination. Many factors have contributed to the push for regulatory reform, including a perceived need to quell public fears in order to ensure participation in research, media coverage of anecdotal events, socialcultural and historical elements, and simply the absence of good reasons not to prevent discrimination on the basis of genetic factors that individuals cannot control. The latter two factors seem particularly relevant to continental Europe where, despite the almost complete lack of evidence, local governments have adopted robust laws and policies to address the perceived problem of genetic discrimination.

As with gene patents and genetic testing-induced harm, it would be misleading to suggest that the ubiquitous policy activity in this domain has been informed by solid evidence of widespread harm. One notable exception is the case of Huntington's disease, for which substantial data about the negative treatment of carriers has been gathered over the years [36]. However, because it is a well-known autosomal dominant condition, even in the absence of genetic tests, discrimination would probably still be possible - and, in the case of life insurance, not without technical justification - on the basis of family history.

\section{ELSI hype?}

The nature and magnitude of ELSI concerns are closely tied to the relevant scientific developments. Given that the conclusions of genetic research have proven to be less definitive than previously anticipated, it should be no surprise that the same trend is found in the context of ELSI. Many of these issues, including those discussed above, flow from assumptions about the predictive power of genetic information. Although it is certainly true that some genetic risk information is highly predictive, we now know that is not the case for most forms of genetic information, particularly regarding common, chronic diseases [37-39].

The slow march of clinical adoption of genomic technologies could, in part, explain the conclusions found in the relevant ELSI research. If genetic information is not, 
in general, highly predictive, then the value of gene patents is low except in unusual cases, and there is no reason for individuals to become overly anxious or fatalistic when faced with genetic test results. It thus seems a dubious cause of institutionalized discrimination; in fact, evidence on genetic discrimination is generally limited to a handful of classic, highly familial, genetic conditions [35].

Nevertheless, policymakers and public discourse often seem wedded to old views of social harm (Table 1) views that are not necessarily supported by empirical data. To be clear, we are not saying that all policy action must be founded on empirical evidence alone. Conceptual analysis and the desire to protect rights and wellestablished ethical norms must and can support a range of policy responses. But when the call for reform is based on the existence of testable harms - as is the case with the issues outlined above - it seems axiomatic that the relevant evidence should guide policy action.

The persistence of these concerns is the result of a wide range of complex forces, including the fact that they may be proxies for general social angst about the impact of science on society. Likewise, they may fit with preexisting social values or help to promote a related policy agenda (for example, the concern about gene patents fits well with the concern about the commercialization of science and health systems). Finally, it is worth considering the role of the ELSI community itself. Just as with the inappropriate 'hype' that has often been associated with the field of genomics [40], there may be a degree of 'ELSI hype' - that is, a possible (and probably inadvertent) exaggerated portrayal of harm and the need for policy reform. Although further research on the existence of this phenomenon is required, the drivers of ELSI hype probably include the biases of scholars, their needs to obtain research funds, media interest in portraying social concerns as immediate and acute, and polarized public debates.

\section{Conclusions}

Some of the untoward effects so often associated with the 'genomic revolution' are less scary than expected. Part of the reason for this reality, at least in part, could be the fact that the ELSI community has been watching and writing about ELSI and fostering a broad public debate. But in many respects, the postulated genomic cataclysm is really a story of the dog that did not bite. There is little evidence, for example, to support the idea that gene patents are having an adverse impact on the research environment, that genetic testing causes long-term anxiety, or that genetic discrimination is a common phenomenon. All of these conclusions - and there is, of course, similar research in other domains of genetics should shape the direction of policy in these areas.
It would be easy to take our observations as an invitation to inaction, and to argue that ELSI studies have been a waste of money and time because evidence of widespread harm has failed to materialize. On the contrary, we argue that ELSI research programs throughout the world have created a healthy culture of skeptical scrutiny, a salutary result for deliberative democracies. Indeed, the ELSI model seems worth emulating - with deliberative commissions and academic ELSI scholarship progressing in parallel with scientific and technical advances, not only for genomics but also other fields (for example, the field of stem cell research often integrates ELSI work). The story could have unfolded through gathering evidence of harm and presenting it to policy makers to rectify problems. In fact, however, it has been much more a tale of ongoing public debate, active outreach to concerned constituencies in part based on ELSI scholarship, and policy change intended to forestall problems before they occur, or as cases arise. So far in the context of genetics, policy change has not generally been driven by evidence and facts, but rather by debate and foresight based on plausible arguments. But when evidence is available - a direct result of the significant commitment to ELSI scholarship - the relevant data should not be ignored. In an era that is striving to embrace evidence-based policy, empirically derived data on the nature and scope of harms should, in general, take precedence over anecdote. If good data exist, they should be cited in policy debates; if data do not exist, then research should be funded to supply them.

New policy decisions loom on the horizon, such as the push for policies to address whole-genome analysis technologies [41] (including the recommendation of laws that would grant individuals exclusive and enduring property rights over their genetic information $[42,43]$ ) and the continuing concerns about DTC testing [44]. And, of course, the debates about gene patents seem likely to continue even after the US Supreme Court hands down its decision on Myriad Genetics. We hope that these policies will also be informed by past and emerging ELSI work. This will require, inter alia, engaging relevant policy makers, making ELSI work accessible, taking steps to avoid 'ELSI hype' and, going forward, ensuring that future ELSI research is responsive to the policy-making community.

Systematic cultivation of ELSI research was an innovation in the new field of genomics in the late 1980s. It should not be chided because it did not save the world from catastrophe. The story is less heroism in the face of adversity than prudence in the face of uncertainty. But policy action should not be founded solely on either speculation or amorphous social angst. We must embrace what the ELSI research tells us. To do otherwise would run counter to the idea of evidence-based policy. 
This article is part of a series on Using and abusing evidence in science and health policy. Other articles in this series can be found at http://www.biomedcentral.com/series/EvidenceUseAbuse

\section{Abbreviations}

DTC, direct-to-consumer; ELSI, Ethical, legal and social implications (or issues),

\section{Competing interests}

The authors declare that they have no competing interests.

\section{Acknowledgments}

TC would like to thank Robyn Hyde-Lay and Ubaka Ogbogu for their assistance, and AllerGen, Networks of Centers of Excellence, Canada and the CCRM for funding support. SC and RCD note that their research is funded in part by grant P50 HG003391 from the National Human Genome Research Institute (NHGRI) and by the Ewing Marion Kauffman Foundation. SC would also like to thank the NHGRI for research funding support (R03 HG005026). The views are those of the authors and not NHGRI, NIH or the Kauffman Foundation. YJ thanks the CIHR Team in Familial Risks of Breast Cancer and the Ministère du Développement économique, de l'Innovation et de l'Exportation du Québec. We would also like to thank the participants of the Using and Abusing Evidence in Health and Science Policy (Banff, Alberta, May 2012) conference for their thoughtful comments.

\section{Author details}

'Health Law and Science Policy Group, University of Alberta, Edmonton, Alberta Canada, T6G 2H5. ${ }^{2}$ Institute for Genome Sciences and Policy, North Building, Duke University, USA Drive, Box 90141 Durham, NC 27708, USA. ${ }^{3}$ Department of Human Genetics, McGill University, 740 Dr. Penfield Avenue, Montreal, Quebec, Canada, H3A OG1.

\section{Published: 26 March 2013}

\section{References}

1. Skirton $\mathrm{H}$, Goldsmith $\mathrm{L}$, Jackson $\mathrm{L}, \mathrm{O}^{\prime}$ Connor $A$ : Direct to consumer genetic testing: a systematic review of position statements, policies and recommendations. Clin Genet 2012, 82:210-218.

2. Genetic Information Nondiscrimination Act. Pub. L. No. 110-233, 122 Stat. 881 (2008).

3. UNESCO: Universal Declaration on the Human Genome and Human Rights. UNESCO; 1997 [http://www.unesco.org/new/en/social-and-human-sciences/ themes/bioethics/human-genome-and-human-rights/]

4. Eisenberg R: Technology policy perspective on the NIH gene patenting controversy. U Pitt L Rev 1993, 55:633-652.

5. Cook-Deegan R, Heaney C: Patents in genomics and human genetics. Annu Rev Genomics Hum Genet 2010, 11:383-425.

6. Merz JF, Kriss AG, Leonard DG, Cho MK: Diagnostic testing fails the test. Nature 2002, 415:577-579.

7. Cho MK, Illangasekare S, Weaver MA, Leonard DG, Merz JF: Effects of patents and licenses on the provision of clinical genetic testing services. $J \mathrm{Mol}$ Diagn 2003, 5:3-8.

8. Cook-Deegan R, Chandrasekharan S, Angrist M: The dangers of diagnostic monopolies. Nature 2009, 458:405-406.

9. Carbone J, Gold ER, Sampat B, Chandrasekharan S, Knowles L, Angrist M, Cook-Deegan R: DNA patents and diagnostics: not a pretty picture. Nat Biotechnol 2010, 28:784-791.

10. Gaisser S, Hopkins MM, Liddell K, Zika E, Ibarreta D: The phantom menace of gene patents. Nature 2009, 458:407-408.

11. Hawkins $\mathrm{N}$ : The impact of human gene patents on genetic testing in the United Kingdom. Genet Med 2011, 13:320-324.

12. Chandrasekharan S, Cook-Deegan R: Gene patents and personalized medicine - what lies ahead? Genome Med 2009, 1:92.

13. Kepler TB, Crossman C, Cook-Deegan R: Metastasizing patent claims on BRCA1. Genomics 2010, 95:312-314.

14. Holman CM: Debunking the myth that whole-genome sequencing infringes thousands of gene patents. Nat Biotechno/ 2012, 30:240-244.

15. Association for Molecular Pathology et al. v. United States Patent and Trademark Office et al. USDC SDNY 09 Civ. 4515, 2010.

16. Caulfield T, Bubela T, Murdoch CJ: Myriad and the mass media: the covering of a gene patent controversy. Genet Med 2007, 9:850-855.
17. Caulfield T, Cook-Deegan RM, Kieff FS, Walsh JP: Evidence and anecdotes: an analysis of human gene patenting controversies. Nat Biotechnol 2006, 24:1091-1094.

18. Caulfield T: Direct-to-consumer testing: if consumers are not anxious, why are policymakers? Hum Genet 2011, 130:23-25.

19. Secretary's Advisory Committee on Genetic Testing: Enhancing the Oversight of Genetic Tests: Recommendations of the SACGT. Bethesda: National Institutes of Health; 2000 [http://oba.od.nih.gov/oba/sacgt/reports/ oversight_report.pdf]

20. The Canadian College of Medical Geneticists Ethics and Policy Committee: CCMG Statement on Direct-to-Consumer Genetic Testing. 2011 [http:// www.ccmg-ccgm.org/documents/Policies Reports and Position Statements/ Position Statements/PosStmt_EPP_DTC_FINAL_20Jan2011.pdf]

21. James KM, Cowl CT, Tilburt JC, Sinicrope PS, Robinson ME, Frimannsdottir KR, Tiedje K, Koenig BA: Impact of direct-to-consumer predictive genomic testing on risk perception and worry among patients receiving routine care in a preventive health clinic. Mayo Clin Proc 2011, 86:933-940.

22. Collins RE, Wright AJ, Marteau TM: Impact of communicating personalized genetic risk information on perceived control over the risk: a systematic review. Genet Med 2011, 13:273-277.

23. Bloss CS, Schork NJ, Topol EJ: Effect of direct-to-consumer genomewide profiling to assess disease risk. N Engl J Med 2011, 364:524-534.

24. Marteau TM, French DP, Griffin SJ, Prevost AT, Sutton S, Watkinson C, Attwood $\mathrm{S}$, Hollands GJ: Effects of communicating DNA-based disease risk estimates on risk-reducing behaviours. Cochrane Database Syst Rev 2010, CD007275.

25. Reid RJ, McBride CM, Alford SH, Price C, Baxevanis AD, Brody LC, Larson EB: Association between health-service use and multiplex genetic testing. Genet Med 2012, 14:852-859.

26. Borry P, van Hellemondt RE, Sprumont D, Jales CF, Rial-Sebbag E, Spranger TM, Curren L, Kaye J, Nys H, Howard H: Legislation on direct-to-consumer genetic testing in seven European countries. Eur J Hum Genet 2012, 20:715-721.

27. Lemmens T: Selective justice, genetic discrimination, and insurance: should we single out genes in our laws? McGill Law J 2000, 45:347-412.

28. Martin DK, Greenwood HL, Nisker J: Public perceptions of ethical issues regarding adult predictive genetic testing. Health Care Anal 2010, 18:103-112

29. Joly Y, Braker M, Le Huynh M: Genetic discrimination in private insurance: global perspectives. New Genet Soc 2010, 29:351-368.

30. Rosthstein MA, Joly Y: Genetic information and insurance underwriting: contemporary issues and approaches in the global economy insurance. In Property and Privacy, Handbook of Genetics and Society: Mapping the New Genomic Era. Edited by Atkinson P, Glasner P, Lock M. New York: Routledge; 2008:127-144.

31. Otlowski M, Taylor S, Bombard Y: Genetic discrimination: international perspectives. Annu Rev Genomics Hum Genet 2012, 13:433-454.

32. Health Insurance Portability and Accountability Act. 45 CFR $\S \S 160.103$, 164.501.

33. Patient Protection and Affordable Care Act. Pub. L. No. 111-148, 124 Stat. 119 (2010), § 2705

34. Greely HT: Banning genetic discrimination. N Engl J Med 2005, 353:865-867.

35. Joly Y, Ngueng Feze I: Genetic discrimination life insurance and evidence: a comprehensive review of 28 empirical studies. BMC Med 2013, 11:25.

36. Erwin C, Williams JK, Juhl AR, Mengeling M, Mills JA, Bombard Y, Hayden MR, Quaid K, Shoulson I, Taylor S, Paulsen JS; I-RESPOND-HD Investigators of the Huntington Study Group: Perception, experience, and response to genetic discrimination in Huntington disease: the international RESPOND-HD study. Am J Med Genet B Neuropsychiatr Genet 2010, 153B:1081-1093.

37. Hall WD, Mathews R, Morley Kl: Being more realistic about the public health impact of genomic medicine. PLoS Med 2010, 7:e1000347.

38. Evans JP, Meslin EM, Marteau TM, Caulfield T: Genomics. Deflating the genomic bubble. Science 2011, 331:861-862.

39. Roberts NJ, Vogelstein JT, Parmigiani G, Kinzler KW, Vogelstein B, Velculescu VE: The predictive capacity of personal genome sequencing. Sci Trans/Med 2012, 4:133ra58.

40. Caulfield T, Condit C: Science and the sources of hype. Public Health Genomics 2012, 15:209-217.

41. Jones M: Beyond GINA, states build patchwork of protections. GenomeWeb Daily News 22 August 2012 [http://www.genomeweb.com/ beyond-gina-states-build-patchwork-protections]

42. Massachusetts state legislature. Senate Bill S01080, 187th General court. Regular session. 
43. Vermont state legislature. House Bill 368. 2011-2012 Legislature. Regular session.

44. American Bar Association: Resolution 114: ABA Urges Direct Access to Diagnostic Medical Testing. 2011 [http://www.abanow. org/2011/07/2011am114

45. American Medical Association: Gene Patenting [http://www.ama-assn.org/ ama/pub/physician-resources/medical-science/genetics-molecularmedicine/related-policy-topics/gene-patenting.page]

46. NSGC Public Policy Committee: Backgrounder on Human Gene Patents. 4 January 2010 [http://www.nsgc.org/Portals/0/Position\%20Statements/ PPC_Patent_Rationale_Final.pdf]

47. Holland JJ: Human Gene Patent Decision to be Decided Down by US Supreme Court. Huffington Post 30 November 2012 [http://www. huffingtonpost.com/2012/12/02/human-gene-patent_n_2220737.html]

48. Critchton M: Patenting life. The New York Times 13 February 2007 [http://www.nytimes.com/2007/02/13/opinion/13crichton.html?_r=0]

49. Gene tests 'create undue stress'. BBC News 15 September 2008 [http://news.bbc.co.uk/2/hi/health/7616073.stm]
50. Lewis R: The Battle of Prenatal Tests. Scientific American Blog 5 December 2012 [http://blogs.scientificamerican.com/guest-blog/2012/12/05/ the-battle-of-the-prenatal-tests]

51. Canadian Colition for Genetic Fairness/Coalition canadienne pour l'équité génétique (CCGF/CCEG) [http://www.ccgf-cceg.ca/]

52. Gene testing exposes us all to discrimination. Sydney Morning Herald 16 February 2010 [http://www.smh.com.au/opinion/editorial/gene-testingexposes-us-all-to-discrimination-20100215-o2ta.html]

53. Heim-Meyers B: Do we need legislation to protect Canadians' genetic rights? The Yes side. Globe and Mail 10 December 2012 [http://www. theglobeandmail.com/news/national/time-to-lead/do-we-need-legislationto-protect-canadians-genetic-rights-the-yes-side/article6188021]

doi:10.1186/gm425

Cite this article as: Caulfield T, et al.: Harm, hype and evidence: ELSI research and policy guidance. Genome Medicine 2013, 5:21. 